Acta Poetica 28 (1-2)

PRIMAVERA-OTOÑO

2007

\title{
La muerte lenta. Um filme falado, de Manoel de Oliveira
}

\author{
Marianela Santoveña Rodríguez
}

Vivimos en una era repleta de imagen y sonido, nuestra vista ha sido educada por el lente de la cámara, y nuestra memoria parece tener banda sonora. En una época en que los significados pasan necesariamente por los medios, sentimos lejana la fábula, se nos empieza a escapar de las manos la novela y, sin embargo, seguimos creyendo en una idea lineal y teleológica de la historia. Sólo que ahora no podemos más que pensar nuestra historia a través de un montaje. La teoría ha rehuido hablar sobre el cine en términos técnicos. Pero el cine mismo no ha temido cuestionar la teoría a través de la técnica. Un gran ejemplo de ello es el cine de Manoel de Oliveira.

We live in an age full of images and sounds, an age when our sight is educated by camera lenses and our memory seems to have a soundtrack. Today, when every meaning is grasped necessarily through the media, we feel far away from fables, we lose grip of novels, and yet, we still believe in a linear, theleological idea of History. Only now we have to think of History in terms of montage. Theory has shunned discussing cinema in technical terms. But cinema itself has not feared questioning theory by means of technique. The movies of Manoel de Oliveira constitute a significant example of this. 

Acta Poetica $28(1-2)$

PRIMAVERA-OTOÑO

2007

Marianela Santoveña Rodríguez

FFyL, UNAM

La muerte lenta.

Um filme falado, de Manoel de Oliveira

Temos a sensação de que as coisas (os objectos de arte) vão ficar para sempre. Mas, os filmes estragam-se. Tudo se estraga. Esta idea é terrível. Tudo acaba por acabar. Até o mundo.

Manoel de Oliveira

¿Y qué son las sirenas?

Las sirenas son creaturas mitad pez, mitad mujer. Son imágenes, son ficciones, son fábulas. Una sirena es una pura invención. Es una creatura fabulosamente textual. Las sirenas son personajes legendarios que cantan el canto más bello. Y son también mitos que encarnan el miedo. Las sirenas son el miedo de Ulises, miedo a no volver a su patria, miedo a no ser recordado, miedo a abandonar la cultura, la civilización, la skholè, la paideia. El miedo es la historia de Ulises, del capitán que selló los oídos de su tripulación con cera y se hizo atar al mástil de su nave, todo para escuchar el canto y, no obstante, volver. El miedo es una larga historia de regresos, de continuidades, de repeticiones. Es una historia de domesticación, de elusión de la catástrofe. El miedo es la historia de un viaje sin 
adioses, donde al final, siempre, nos espera un paisaje idéntico al que dejamos, el mismo paisaje, cada vez más cerca, cada vez más a la mano, cada vez a menor distancia, porque conforme pasa el tiempo el viaje no hace sino aumentar de velocidad —en barco, en tren, en avión; destruyendo, si es necesario, lo que se interponga - para llegar lo más pronto posible a ese destino sabido de memoria.

Quizás contamos historias para hacer algo de nuestro tiempo. No sólo para que éste pase, sino para hacerlo pasar de la manera que consideramos la mejor posible. Contamos historias para no tenerle miedo al tiempo, para abarcarlo, medirlo, conformarlo, darle - como quería Aristóteles- un principio, un medio y un fin. Así, metaforizamos, alegorizamos cada instante, traducimos lo desconocido en conocido y evadimos lo inaudito. ¿Penélope? Sea quien sea, Penélope está en casa, esperándonos...

La Odisea es, entre otras tantas cosas, una idea de la historia. Es un texto y una fábula que nos permite dar sentido al tiempo, al movimiento, a la acción y a la palabra. Todos los griegos que firmaron bajo la rúbrica de Homero inventaron esta idea de la historia. Pero no sólo la inventaron, la hicieron necesaria. ¿Quién, desde entonces, no necesita una fábula? Al filo de la modernidad y pese a su disposición racional, el mismo Kant se había resignado a ese viejo deseo. Porque, aun con todas las virtudes de la razón, requería de un idea de la historia, la echaba en falta, aunque fuera ya bajo la forma de una novela - la novela de los fines, le llamaba-. Y, claro, ya en plena época moderna, echando mano de la síntesis de saberes, Hegel convirtió la necesidad en vicio y la fábula en filosofía. Todo pasa por la historia, todo pasa en la medida en que lo contamos.

Nosotros, en una era repleta de imagen y sonido, con una vista educada por el lente de la cámara, con una memoria que parece tener banda sonora, seguimos anhelando esa idea. Y aun- 
que sentimos lejana la fábula, aunque se nos empieza a escapar de las manos la novela, no podemos más que pensar nuestra historia a través de un montaje. "El montaje — decía Gilles Deleuze- es esa operación que recae sobre las imágenes-movimiento para desprender de ellas el todo, la idea, es decir, la imagen del tiempo". ${ }^{1}$ Con el montaje, se ajusta la duración y la intensidad de cada acción en su presente, se le asigna un principio y un fin, se la une con otras acciones y, a través de cortes, raccords y falsos raccords, se crea un tiempo total, una idea de la historia. Las secuencias de una película comparten espacios, luces, vestuarios y escenografías a través del montaje. Y es en esta comunión ilusoria, en esta continuidad fabulosamente textual donde se juega la suerte de los personajes $-\mathrm{y}$, con la de ellos, la de todos nosotros.

Ningún montaje — cuando hay en él en verdad una idea del tiempo- es mejor o peor que otro. Ninguno constituye un progreso respecto del anterior. Cada uno es, eso sí, un mundo, una manera de habitar nuestro tiempo. Ya lo concibamos de manera orgánica o dialéctica, dominado por el movimiento o por la luz, el montaje da cuerpo a nuestras historias, a las que contamos y a las que vivimos. Y si su idea cambia, quién sabe... la Odisea podría cambiar.

¿Qué pasaría con una historia que comenzara justamente por los adioses? ¿Qué pasaría con un Ulises moderno que zarpa desde Portugal siendo aún niño? ¿Qué pasaría con ese Ulises no sólo niño, sino nacido mujer? Um filme falado (Una película hablada), de Manoel de Oliveira, es la historia de María Joana, una pequeña niña que en julio de 2001, acompañada por su madre, una distinguida profesora de historia, zarpa de Lisboa y atraviesa milenios de civilización para encontrarse con su padre en Bombay. De la forma en que Oliveira haya contado su historia depende el destino de María Joana.

\footnotetext{
${ }^{1}$ Gilles Deleuze, La imagen movimiento. Estudios sobre cine 1, 3a edición, Barcelona, Paidós, 1994, p. 51.
} 
Podríamos imaginar ese destino de muchas maneras. Contamos con un cierto material: María Joana y su madre zarpan de Lisboa; en cada puerto — de Francia, de Italia, de Grecia, de Turquía, de Egipto - descubren vestigios de los romanos, los fenicios, los griegos, los árabes, los egipcios; en el trayecto se unen al crucero tres mujeres fascinantes (fascinantes en el cine, en la vida, en la película): Catherine Deneuve, una empresaria; Stefania Sandrelli, una diva; Irene Papas, una artista. María Joana avista destellos de la historia de Occidente, mira desde lejos y con curiosidad a esas tres magníficas mujeres, casi tiene la oportunidad de compartir una cena políglota con ellas y el capitán, interpretado por John Malkovich. Después, en medio de todos los tiempos y todas las lenguas, sobrevendrá el final de su historia.

Podría ser un bocado de dulce para Griffith, el maestro del cine norteamericano contemporáneo: toda la cultura de la modernidad con todo y Revolución francesa en un primer plano de Catherine Deneuve, seguido, claro, de un destello de Marsella. Toda la cultura romana en el rostro de Stefania Sandre1li, que converge con una imagen de Italia. Toda la herencia griega en el gesto protagónico de Irene Papas, que se une a la imagen del Partenón, con un sacerdote griego ortodoxo incluido en el paisaje. Lo viejo y lo nuevo se alternan y concurren. Se tocan cada vez con más prisa, en una secuencia de aceleración. El tiempo es un "gran círculo [en] espiral recogiendo el conjunto del movimiento del universo". ${ }^{2}$ La historia es orgánica y todo ha valido la pena. Es una herencia que recibirá Maria Joana como un regalo...

O no.

Un desafío más para los admiradores de la dialéctica: una historia de contradicciones fatales, la triste historia de la humanidad que ha olvidado la lengua griega, lo mismo que los

${ }^{2}$ Gilles Deleuze, La imagen-movimiento, p. 54. 
ideales de la Revolución francesa. Una contradicción se desvanece en otra. "El montaje de oposición sustituye al montaje paralelo, bajo la ley dialéctica del Uno que se divide para formar la unidad nueva más elevada". ${ }^{3}$ Como en un filme de Eisenstein, los planos no se alternan, no convergen. El barco avanza hacia su propia catástrofe. Pero quizás María Joana pertenezca a una nueva generación, más elevada, más consciente...

O no.

Pasto para una larga reflexión fílmica con toda la elegancia de la escuela clásica francesa: cada pequeño movimiento individual se refleja en el gran desfile de la historia. María Joana es un pequeño componente de un gran reloj. Su respiración, su voz, son un susurro o un reflejo de la gran historia... de la inauguración del canal de Suez, por ejemplo, que aparece representado en una pintura ante los ojos azorados de la niña, como si la pintura fuese su música de fondo... Una gran empresa del poderío humano, llena de grandeza y de desgracias. Las imágenes se superponen hasta perderse en lo pictórico. El movimiento escala. El mundo es una pieza musical de contrastes.

O no.

Porque Oliveira no lo quiso así. Oliveira eligió la voz pura y la lentitud. Sobre todo, la voz y la lentitud en contraposición a la velocidad y el ruido. No hay en sus películas, no hay en $U m$ filme falado música que anuncie el destino. No hay aceleración. No hay travellings, ni planos de grúa, ni close ups, ni disolvencias. No hay actuaciones patéticas. Mucho menos algún efecto especial. El filme es, en verdad, una película hablada.

Lenta como una espera cotidiana.

Brutal, porque nos conduce hacia el cataclismo a ciegas.

En el montaje de Oliveira, la historia deja de ser una vida orgánica, una sucesión dialéctica o una composición mecáni-

${ }^{3}$ Gilles Deleuze, La imagen-movimiento, p. 57. 
ca. Ahí, en el lento vaivén del mar, entre las pausadas conversaciones a la mesa del capitán, la historia se configura como una muerte lenta, inevitable que, pese a todo, ofrece grandeza y encanto.

Decía Jacques Derrida que la experiencia de la velocidad no sólo está íntimamente ligada a la experiencia de la guerra, sino que sus mutaciones transforman el dispositivo entero de una cultura, sus formas de la memoria y del miedo. ${ }^{4}$ Y lo decía respecto de la amenaza nuclear, del peligro de desaparición sin resto de la cultura, el peligro del olvido de nuestras vidas y de nuestros archivos. Hemos llegado hoy a un punto de aceleración tal que una fábula como la guerra nuclear desata la carrera armamentista. Un punto de aceleración tal que la guerra ya no es sólo una cuestión de destrucción, sino de destrucción anticipada. Los debates en torno al "first use", "no first use" y "no use" del arma nuclear recuerdan a la "guerra preventiva" de hoy. Se trata de un fabuloso esfuerzo de aniquilación tejido en torno a un suceso que aún no ha tenido lugar. Un suceso, también él, como las sirenas, fabulosamente textual que encarna el miedo, que suscita la tentación del regreso.

Pero todo el miedo del mundo, de nuestro mundo, no es sino la negativa a darle muerte a una idea. Nuestra idea de la historia, al menos hoy, al menos la que es dominante, está fundada en el miedo. Y provoca miedo. Nuestra idea de la historia, al menos hoy, la que es dominante, nos impone una experiencia de la aceleración. El miedo acelerado es el terror. El terror es el miedo del otro que, precavidamente y como buen discípulo, se adelanta a nuestro pensamiento de anticipación: ataca primero, antes de que nosotros aceleremos más y destruyamos lo que sea con tal de regresar, de volver, de reiterar la mismidad de nuestra cultura y demostrar triunfantes que, sí, Penélope sigue esperando...

\footnotetext{
${ }^{4}$ Jacques Derrida, "No apocalypse, not now (a toda velocidad, siete misiles, siete misivas)", en Cómo no hablar, Barcelona, Proyecto a, 1997, p. 139 ss.
} 
Es justamente ante el terror como Oliveira sostiene la lentitud y la voz.

En una secuencia cercana al final de la película, Irene Papas canta durante más de ocho minutos. En griego. Sin cortes. Es la canción la que se impone sobre la cámara. La canción lenta y melancólica. La lengua griega. La hermosa voz.

María Joana nunca verá de nuevo a su padre. Nunca regresará a Lisboa. Y, quizás, nunca habrá tenido miedo. Habrá realizado un viaje lento en el que la única fábula, la única novela, el único montaje habrá sido la palabra. Una suerte de pragmática recorre el filme de Oliveira. En él, cada acto del habla constativo es, a la vez, un acto del habla realizativo. Cada lengua habrá sido una vida, una leyenda, una civilización, un mito. Cada timbre de voz se negará a ser rebasado por la aceleración y la catástrofe. Frente a lo fabulosamente textual del miedo, Oliveira opondrá la suave acción de la palabra hablada. En su montaje, el terror de la destrucción, el terror literal, el terrorismo, no invitarán a la moraleja, no invitarán a un mito de retorno - retorno a una patria, retorno a un posible sentido original de la democracia, a los derechos del hombre, a la razón, a cualquier salvaguarda de Occidente-, el terror no invitará a la continuidad, al falso raccord. En lugar de ello, Um filme falado lanzará sobre nosotros el desafío de hablar pese a todo, de cantar en la propia lengua, pese a todo, lentamente, a partir del silencio, sin miedo, sin anticipación y sin ayuda.

En medio de la lentitud prodigiosa del canto de Irene Papas, el capitán es advertido sobre la colocación de varias bombas en el barco en el que viajan todos los personajes. Silenciosamente, en medio del canto, se cierne el peligro. Cuando la tripulación sea evacuada, María Joana regresará a su camarote por una muñeca que había olvidado. Una muñeca que le regaló el capitán. Morirá cuando el barco estalle. 
Y podríamos decir de esta pequeña que no se previno, como Ulises, y no supo ver y huir de lo inaudito. Pero, ¿podríamos decirlo si lo inaudito la rodeó todo el tiempo, si estuvo ahí, con ella, fascinándola y guiándola? ¿Podríamos decirlo aunque lo inaudito haya sido la historia que recibió de Occidente, el miedo encarnado en esa historia? ¿Aunque lo inaudito fuese el miedo a perder esa idea de esa historia? No hay vuelta atrás, no hay regreso a Itaca. Sólo el rostro del capitán, mudo. Sólo la conciencia tácita de la muerte de María Joana y de su madre, distinguida historiadora. Sólo la suposición de que las tres mujeres sin hijos habrán salvado la vida. Y, pese a todo, hay que hablar. No por una idea, por un puro significante, no por una pura invención, por una fábula, sino por una palabra que refunda el tiempo. Con sirenas, sí, pero sin regresos, sin anticipaciones, sin paisajes idénticos, sin trucos de continuidad. Por una historia hablada, por una imagen lenta. "¿Y qué son las sirenas?" Ojalá dejen de ser un mito del miedo y sean, con su canto, un acto, una palabra. 